\title{
衛星搭載用精密作業テレロボットの開発
}

\author{
町田和 雄 ${ }^{* 1}$ 三上龍 男 ${ }^{* 2}$ 秋田 健 三*3

\section{Development of Precise Telerobotic System for Unmanned Spacecraft}

\author{
Kazuo Machida ${ }^{* 1}$, Tatsuo Mikami ${ }^{* 2}$ and Kenzo Akita $^{* 3}$
}

\begin{abstract}
Space robots performing precise servicing tasks in unmanned facilities will be indispensable in space activity of the 21 st century. This paper presents the development of a precise telerobotic system which is the world's first precise extravehicular robot aboard the satellite, ETS-VII. The robot has the features of skill and autonomy for handling various parts in space through a three-finger multisensory hand. Firstly, we discuss the requirements for in-orbit precise servicing by a robot and system constraints to integrate into the satellite, and present the total system design for space telerobotic experiment. Secondly, we describe the design of robot mechatronics adapt to space use. The launch lock mechanisms and reconfiguring method of the robot in orbit are also described. Thirdly, an architecture and design of the onboard control computer system to manage various tasks flexibly and safely are presented. Finally, the multisensory based control for precise task execution and development result of the flight model are presented. The system was launched, and initial checkout reveals the system works well in-orbit.
\end{abstract}

Key Words: Space Robot, Precise Telerobotics, Multisensory Hand, Extravehicular Robot, Space Experiment

\section{1. はじめに}

宇宙空間の利用が大規模化, 多様化するに伴い, 危険な宇宙船 外で人間に代わり精密作業を行うロボットが求められてくる.現 状の船外ロボットはペイロードに付けた大きなフィクスチャを ツールでつかんで運搬し,設置場所の結合機構で固定してもらう もので[1][2], 部品を扱う精密作業性を持つに到ってない. 将来 の宇宙におけるロボットの役割を拡げるには, 部品レベルの精密 作業能力を有する船外ロボットが重要となる.船内の精密ロボッ 卜実験としてROTEXが知られている[3].このロボットはスペー スラブのラック内で動作するもので, 宇宙環境に曝される船外で は使用できない.また, 有人システムの一部として組込まれてお り, 完全無人化されたシステムになっていない.さらに,エンド エフェクタは1自由度グリッパなので作業対象に把持フィクス チャを要するなどの制約がある.

筆者らは宇宙船外で精密作業を行うテレロボットを開発し[4]

原稿受付 1998 年 5 月 12 日

・電子技術総合研究所

?富士通株式会社

*3無人宇宙実験システム研究開発機構

" Electrotechnical Laboratory, MITI

${ }^{* 2}$ Fujitsu LTD

${ }^{* 3}$ Institute for Unmanned Space Experiment Free-Flyer
[5]，技術試験衛星 VII 型（ETS-VII）において宇宙実験を行って いる.このロボットは3指多重センサハンドによる多様な精密作 業性を有すること, 宇宙暴露環境で作業可能なこと, 衛星搭載機 器として完全無人化されていること,船外作業の多様性に対応す るため他のロボットアームへハンドを結合して精密作業が可能な ことが新規な特徵であり, 無人宇宙船外で精密作業を行うテレロ ボットとしては世界に先駆けたものである.

本論文ではこのロボットシステムの設計と衛星搭載モデルの開 発について述べる。まず, 船外精密作業ロボットの要件とシステ ム制約条件を述べ,これらを満たし衛星に搭載可能なシステム設 計について述べる. 次に, 宇宙適応化のためのロボットメカトロ ニクスの設計について述べる。次いで, 多重センサを用いた精密 作業制御法と衛星搭載モデルの開発結果を述べる。

\section{2. 船外精密作業ロボットのシステム設計}

\section{1 ミッション}

船外精密テレロボット技術をETS-VIIの制約範囲で可能な限り 実証する実験システムを考える。概念検討の流れを Fig.1に示 す. 軌道上精密サービス作業の要件を抽出し, 衛星システム制約 条件と宇宙環境条件のもとで実現可能な実験システムのベースラ インを定めることにする.まず, 軌道上精密サービス作業に対す るロボットへの一般的要件であるが, 罒の左に示すように

i) 宇宙ではサービス対象のスケールが一般に大きいため広い作 
General requirements for dexterous in-orbit servicing

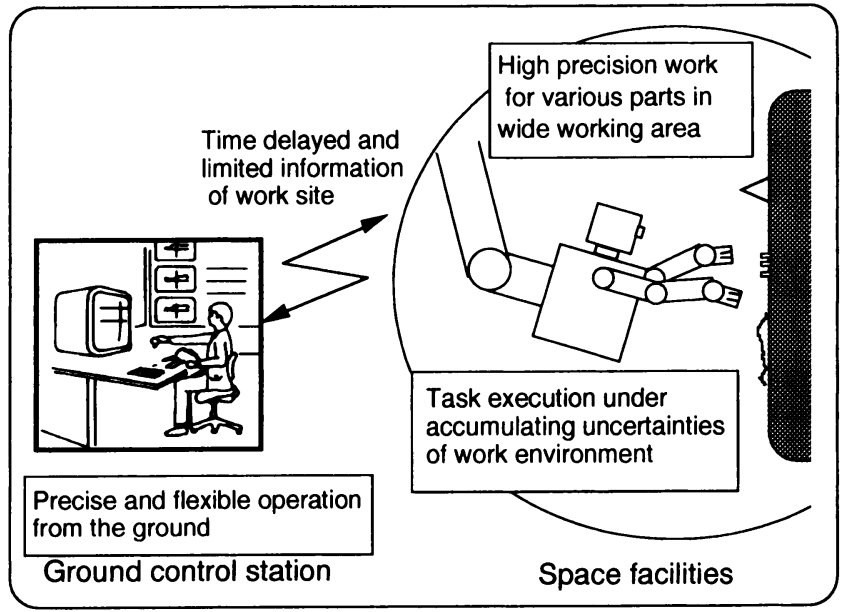

System constraints

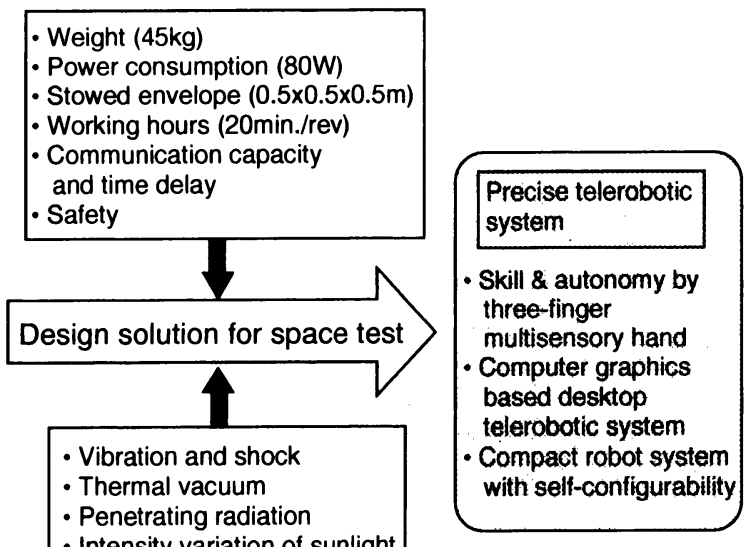

Fig.1 Design strategy and solution for space test of precise telerobotic system

業範冊が要求されるとともに,ローカルには多種多様な部品を位 置や力の精密な制御のもとにハンドリングすることが要求され る.

ii）サービス作業は多数の小作業の積み重ねからなり，作業環 境や対象の不確定性が累積していくため,これらの計測を作業の 進行に応じインタラクティブに行える必要がある.

iii）地上からの精密かつ柔軟な運用性が要求される。この場 合,作業場所が遠い宇宙にあるため作業情報の取得および地上へ の伝達は制限され, かつ, 時間遅れに対処しなければならない.

宇宙実験はこれらの要件に対応する技術の習得, 検証を行うこ とを主目的とした。

\section{2 制約条件}

ETS-VII は高度 $550[\mathrm{~km}]$, 傾斜角 35 度の円軌道を約 95 分で周 回する親子衛星で, 重量約 2,500 [kg]のチエーサ衛星とランデ ブードッキングの対象となる $380[\mathrm{~kg}]$ の夕ーゲット衛星からなる [6]. ロボットはチエーサ衛星の地球指向面に搭載される。本搭 載機器に対する衛星システムからの制約条件には次のものがあ る。重量，電力に関しては $45[\mathrm{~kg}], 80[\mathrm{~W}]$ 以下，ロボット機構 系の収納空間は $50[\mathrm{~cm}]$ 立方以内である。ロボットの作業は静止 軌道のデータ中継衛星と ETS-VII が通信可能でかつ日照の時間 帯に行い，1周回で 20 分を 1 単位として割り当てられている。口 ボットの作業単位はこの時間で閉じるように計画するとともに, 通信切れに備え臨機応変な処置ができるシステムとする必要があ る. 地上系と軌道上系との通信時間遅れは, 米国のデー夕中継衛 星（TDRS）を用いた通信ネットワークを使う場合，経路による が 4 10秒と見積もられている．安全性に関しては，いかなる 場合も物体を空間に放出しないこと,および, 暴走しないための 多重の対策と万一暴走しても衛星の他機器を破損しないことなど が要求される。

環境条件としては打ち上げ時の振動・衝撃や軌道上での真空, 熱，放射線などがありこれらに耐えるハードウエアが必要であ る。これらの主な設計要求条件を Table 1 に示す。また，軌道周 回中に作業面の照度は時々刻々と変動するので視覚系はこれに対
Table 1 Space environmental design requirements

\begin{tabular}{|c|c|}
\hline Environment & Specifications \\
\hline Vibration (Z-axis) & $\begin{array}{l}\text { Sine wave }(20 c t / \mathrm{min}) \\
\text { 5-15Hz: } 10 \mathrm{G} \\
\text { 15-100Hz: } 25 \mathrm{G} \\
\text { Random wave }(4.4 \mathrm{~min}) \\
\text { 19.7Grms }(20-2000 \mathrm{~Hz})\end{array}$ \\
\hline Shock & $\begin{array}{l}\text { Shock response spectrum } \\
100-600 \mathrm{~Hz}:+8 \mathrm{db} / \mathrm{oct} \\
600-4000 \mathrm{~Hz}: 1000 \mathrm{G}\end{array}$ \\
\hline Vacuum & $10^{-6} \mathrm{~Pa}$ \\
\hline Thermal environment & $\begin{array}{l}\text { Solar radiation: } 1289-1421 \mathrm{~W} / \mathrm{m} 2 \\
\text { Earth emission: } 189-261 \mathrm{~W} / \mathrm{m} 2 \\
\text { Albedo coefficent: } 0.2-0.4 \\
\text { Satellie earth-panel: }-40-+60 \mathrm{deg} \mathrm{C}\end{array}$ \\
\hline Penetrating radiation & 21.5 Gy (Aluminum shield: $1 \mathrm{~mm}$ ) \\
\hline
\end{tabular}

応する必要がある。さらに, 地上試験で調整された計測・制御の パラメー夕は宇宙で較正する機能が必要である。

\section{3 システム設計}

2.3.1 テレロボットシステム

2.1 節に述べた船外精密サービス作業の要件に対応しテレロ ボットシステムを次のように設計した。

i）位置と力を精密に調整できる能動 3 自由度の指と, 受動 4 自 由度の柔軟な手首を有するセミデクステラスなハンドを搭載す る。

ii）ハンド回りに非接触と接触の 5 種類のセンサを奉装し, 多 重センサによる遠隔センシングが行えるようにする。

iii）搭載側に部分自律の機能を持たせ局所精細作業の実行のレ ベルを分担させ,地上系で大局的な環境認識と作業指令発信のレ ベルを受け持つ分散型テレロボット構成とする。 
宇宙機器の重量, スペース, 消費電力の制限は厳しく, また, 真空, 熱, 放射線の過酷な環境の中で高い信頼度で働かなくては ならないためその開発コス卜は大きなものとなる.したがってロ ボット制御系の軌道上構成はローカルな自律性を満たす機能にと どめ, 制御周期が遅くてもよい上位レベルの知的制御や動作監視 は計算機グラフィックスベーストのテレロボティクス手法により 地上運用系で行うことを設計の基本とした.以上のことから構築 した宇宙実験システムの全体概念を Fig.2に示す.

衛星を含めたテレロボットシステムの制御情報全体の流れを Fig.3に示す。網掛け部が本システムのコンポネントである. ETS-VIIの搭載ロボット系, デー夕処理通信系, NASAのデー夕 中継衛星 (TDRS), 通信ネットワーク系 (NASCOM)，拈よび筑 波宇宙センタの地上衛星運用系, 地上ロボット運用系を結ぶ空間 的に巨大なループのテレロボットシステムを構成している.地上 系と搭載ロボット系の間はパケット化したデー夕により,アップ

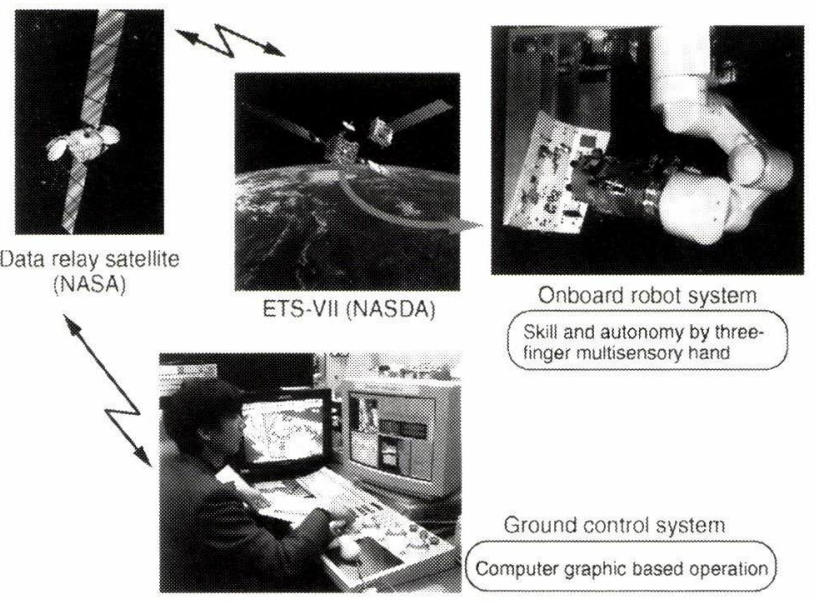

Fig.2 Construction of space telerobotic system
リンク $4[\mathrm{kbps}]$, ダウンリンク $1.5[\mathrm{Mbps}]$ のレートで通信される. ダウンリンクには1.2[Mbps]のTV画像データのほか 12 [kbps]の 実験テレメトリデータが含まれる.制御ソフトウエアは新たな技 術実験が随時できるよう実験内容に応じて地上からアップロード する方式とした、ロボットの運用は地上でのスーパーバイズのも とに自律的に作業を実行する多重センサベースト自律制御を主と し，他に地上からの遠隔操作，および両者をマージした自律・遠 隔融合操作の三つのモードを可能とした。遠隔操作では動作指 令を $4[\mathrm{~Hz}]$ で送信する．TV画像に関してはモニタカメラによる ロボット全体像とハンドアイカメラによる作業面のクローズアッ プ像を地上に送信する。いずれも通信容量の制限からモノクロ画 像を JPEG 圧縮し，2フレーム/秒のレートで送る。ハンドアイ カメラの生画像は搭載系で処理し自律制御に用いる。設計したシ ステムの主要諸元を Table 2 にまとめる.

\subsection{2 ロボット実験部}

ロボット実験部は長さ $0.7[\mathrm{~m}]$ 級の小型アーム, ハンド，タス クボードから構成した.タスクボードにはロボット作業のための 様々な部品を取り付ける。打ち上げコンフィギュレーションは寸 法制限と振動・衝撃条件を満たすためアームとハンドは分離して 固定する方式とした.軌道上では作業形態に自ら再構成する機能 を持たせる.宇宙実験はこのロボットシステムのみで行う単独実 験と，宇宙開発事業団が開発する長さ約 $2.4[\mathrm{~m}]$ の大型アームに このハンドを結合し,ターゲット衛星のサービス作業を行うハン ドノ大型アーム結合実験の2形態で行えるようにする。後者では 大型アームをマク口位置決め装置として用い, 広い領域での精密 作業実験を行う。実験夕スクは将来の宇宙機器の保守に必要とな る主な作業要素を切り出して次のように設定した。単独実験では 電気コネクタの着脱, ボルトファスナの着脱, 浮遊部品の捕獲, ソーラーセルシート展開による発電, 熱ブランケット張付, ワイ ヤ配線などの精密作業を行う[5]，また，日陰時にもLEDの照明 を用いた電気コネクタの着脱実験を試みる。これらの実験は

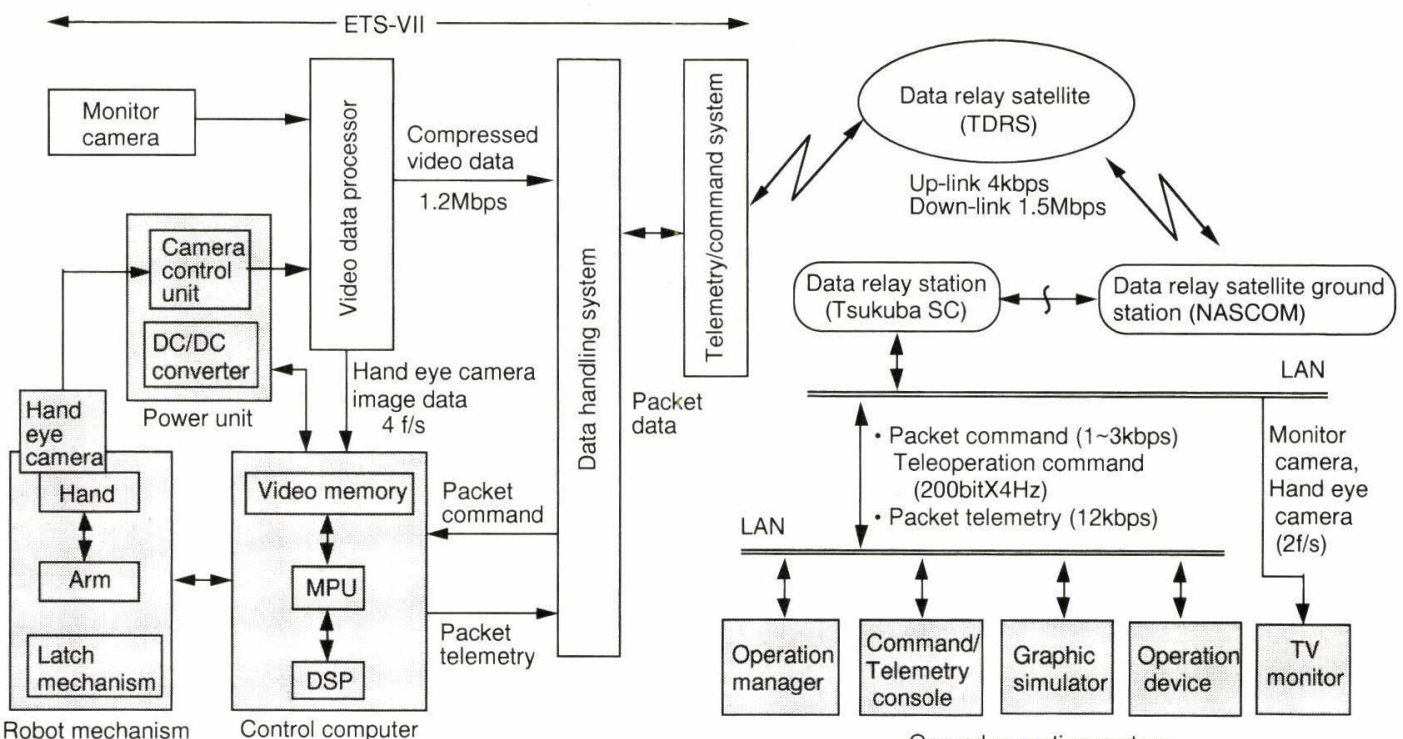

Fig.3 Control signal flow of whole space telerobotic system 
Table 2 Specifications of space telerobotic system

\begin{tabular}{|l|l|}
\hline Total system mass & $45 \mathrm{~kg}$ \\
Dimensions (stowed) & $500 \times 480 \times 480 \mathrm{~mm}$ \\
Average power & $80 \mathrm{~W}$ \\
Hand & 3 \\
DOF & $30 \mathrm{~N}$ \\
Grip force & $0.15 \mathrm{~mm} / \mathrm{N}(\mathrm{x}, \mathrm{y})$ \\
Compliance & $0.075 \mathrm{~mm} / \mathrm{N}(\mathrm{z})$ \\
& $3 \mathrm{deg} / \mathrm{Nm}$ (roll) \\
Mini-arm & 5 \\
DOF & $716 \mathrm{~mm}$ (from base to hand) \\
Length & $\pm 0.5 \mathrm{~mm}, \pm 0.3 \mathrm{deg}$ \\
Accuracy (relative) & $40 \mathrm{~N}, 7 \mathrm{Nm}$ \\
Tip force, torque & $1.4 \mathrm{Nm} / 2.25 \mathrm{rpm}$ \\
Torque driver & \\
Telemetry/Command & $200 \mathrm{bits} \mathrm{x} 4 \mathrm{~Hz}$ \\
Teleoperation command & $12 \mathrm{kbps}$ \\
Packet telemetry & \\
Video data (down link) & $2 \mathrm{ch}, \mathrm{JPEG}$ compressed \\
Channel & monochrome \\
& 2 frame/s \\
Frame rate & 1.5 years \\
Mission period &
\end{tabular}

Fig.4に示すタスクボードの部品を使って行う. 部品は打ち上げ 時, ロンチロック機構で固定し, 軌道上でロボットハンドにより 解放する.ハンドを大型アームに取り付けた結合実験では, ター ゲット衛星のコネクタ着脱とサンプルの回収を試みる.

\section{3. ロボットメカトロニクスの設計}

ここでは上記システムを実現するためのロボットメカトロニク スの設計について宇宙適応化の観点から述べる.

3.1 ロボットアーム

アームは多関節型とし, 各関節のアクチュエータにはDCブラ シレスモータとハーモニックドライブの組み合わせを用いた。 サーボセンサにはレゾルバを用い, 原点センサとリミットセンサ には高周波発振型の近接センサを用いた.各関節のトルクは前述 のタスクを行うため, 無重力で先端力 40 [N], 7 [Nm]が得られる ことを条件に配分した。関節アクチュエータの潤滑には, 宇宙の 真空はもちろん地上大気で動作試験できるようPFPE (PerfluoroPolyether) を基油, PTFEを増ちょう剤とし $\mathrm{MoS}_{2}$ を添加したグ リースを用いた。関節の温度制御は, 待機時はサーマルペイント と多層インシュレータにより軌道上保管温度を維持し, 実験時に 各関節に配したヒータにより能動熱制御を行う方式とした. 熱解 析により待機期間の関節の最低温度は低温ケース（太陽角 0 度） で $-17^{\circ} \mathrm{C}$, 実験時の最高温度は高温ケース (太陽角 58.5 度) で $+46^{\circ} \mathrm{C}$ と見積もられ, 許容温度範囲に収吼らる見通しを得てい る.なお，多層インシュレー夕の最外層は白色のベータークロス を用い太陽光の反射を抑え視覚系の障害にならないようにした。

アームの先端にはハンド結合用ッールを取り付けた.ツールは Fig.5に示すようにステッピングモータを平歯車で減速してカム を駆動し, カムフォロワを介しクランプ爪を外側に倒し, ハンド 側のフィクスチャの溝に爪を挿入して結合する構造とした.ハン ドの固定後, トルクドライバによりハンド側フィクチャのボルト を回転させコネクタをスライドして結合させ,アーム/ハンド間 の電気的結合を行う。トルクドライバのアクチュエータにはス

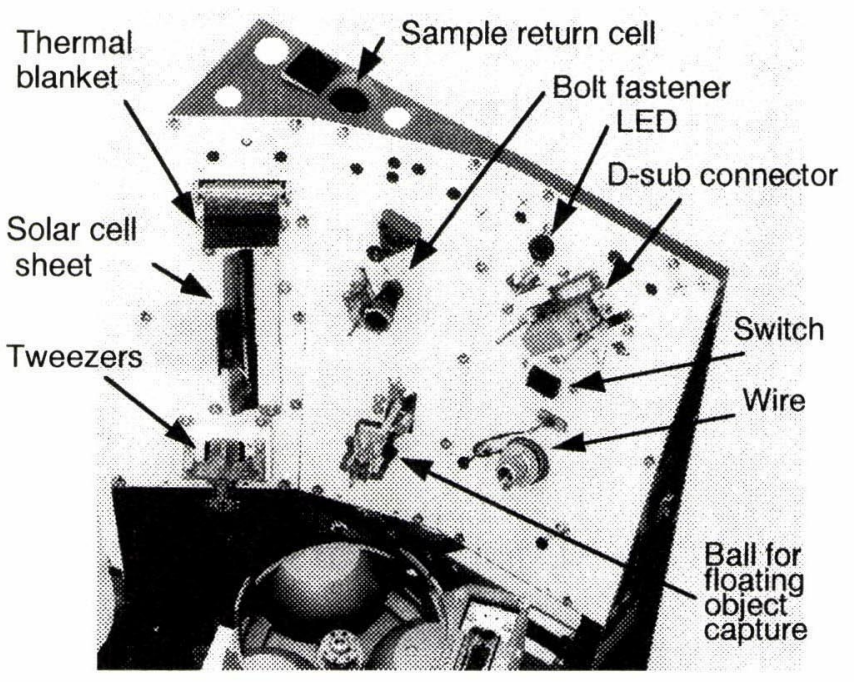

Fig.4 Taskboard and work cells

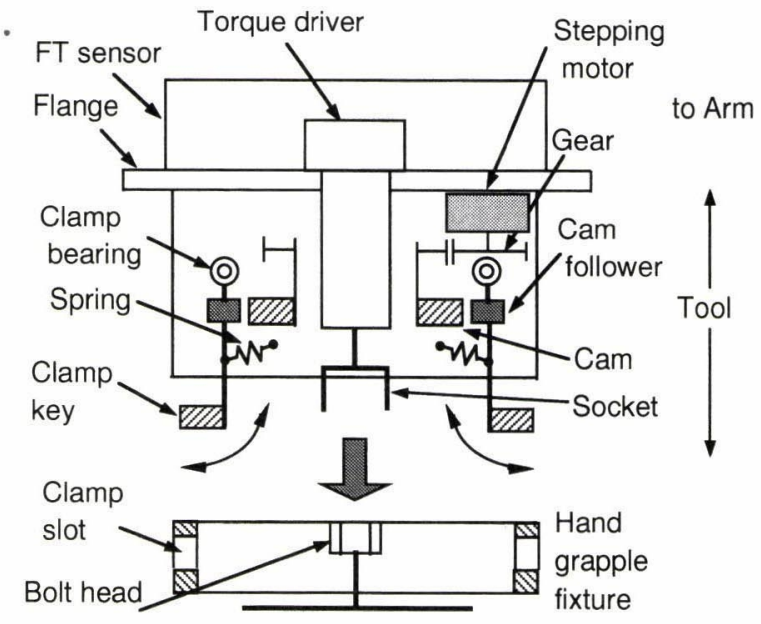

Fig.5 Wrist tool mechanism for hand connection

テッピングモータと遊星ギアの組み合わせを用いた。また，ソ ケットにはスライド式のエスケープ機構を配しハンド結合時のボ ルトヘッドとの位相差による干渉を回避した。このッールは後述 するように打ち上げ時のアーム先端固定にも用いる.

\section{2 ハンド}

ハンド設計の基本指針は, 多指により多様な部品を精度よく八 ンドリングできること, 多重センサにより自律性を向上させるこ とにある.前者については, 宇宙用としてシンプルで信頼性の高 い3 指機構, 搭載計算機の負荷の少ない精密位置補償方式, 多様 な形状の部品に対し宇宙空間で「落とす」ことのない指の把持安 定性を得ることがポイントとなった。 そこで, Fig.6に示したよ うに，指機構を親指に相当する直動指 $\mathrm{A}$ ，および，人差し指，中 指に相当する 2 本の回転指 B, Cで構成した。回転指には圧覚セ ンサを取り付け, 接触検出や把持力制御ができるようにした。こ の方式は2指グリッパの対象物形状に対する適応性の低さと, 多 
Hand mechanism

- Simple and reliable three-finger mechanism - Precise control without increase of onboard computer load - Grasping robustness for various objects
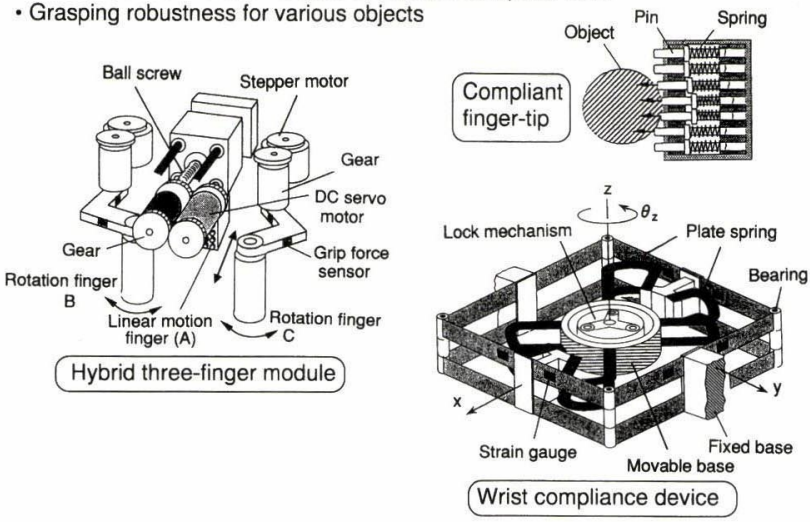

Fig.6 Design of hand mechanism

関節指の把持安定性の久如, 制御の複雑さを回避したもので, 両 者の中間的位置にあるものと考えられる。精密位置補償に関して は指の自由度に加え, 手首の板バネ式の 4 自由度コンプライアン ス機構により実現した。また，コンプライアントな馿染み機構を 直動指に採用し把持の多様性と安定性を増した。これらの三つの 機構は微細な位置や力を調整する柔らかい指と手首として働き, 搭載計算機への過度な負担を避けつつ, 把持の多様性, 信頼性, 精密作業性を与えることができた[7]．多重センサに関しては八 ンドアイカメラ,レーザビーム式近接距離センサ, コンプライア ンス機構に付けた微小変位センサ, 指の圧覚センサ, 手首の力. トルクセンサの 5 種類をハンド回りに集積させ, マクロからマイ クロなセンシングを行う。また，日㓌時にも微細作業ができるよ う低消費電力の赤色 LEDアレーによる照明を備えた。

ハンドのフライトモデルの外観を Fig.7 に示す. ハンドの八ウ ジングには指抄よびコンプライアンスロック機構を駆動するアク チュエータとその制御インタフェース, 拈よび多重センサ信号を 処理しアームとシリアル通信する信号処理部を組み込んだ.コン プライアンスロックは主としてアーム移動中に働かせ,手先の振 動を抑制し速やかな高精度位置決めを可能とさせる。ハンドの手 首部には結合フィクスチャを取付け,インタフェースを標準化す ることにより各種のロボットアームと結合可能にした。

\section{3 打ち上げ固定と軌道上再構成}

\subsection{1 アーム固定機構}

ロボット機構は打ち上げ時には耐振動・衝撃と容積制限のた め, 収納姿勢で固定し, 打ち上げ後自力で作業形態に再構成する 必要がある. 打ち上げ時の振動・衝撃は非常に過酷で, シリアル リンクの多関節アームでは固定法が大きな課題となる。ここでは 固有振動数 $80 \mathrm{~Hz}$ 以上を固定剛性の目標値とした. 固定点を増す と剛性は増すが, 重量増や解放時の信頼度の直列接続による低下 を招くため十分なトレードオフが必要である。そこでいくつかの 固定法に対し, I-DEASを用い数值構造解析を行った. Fig.8にそ の代表ケースを示す.(a)はアームにハンドを結合した状態でハン ドを固定する方式, (b)はハンドを分離して別に固定し、アームの 手首を固定する方式, (c)は(b)方式の剛性をさらに高めるため肘部

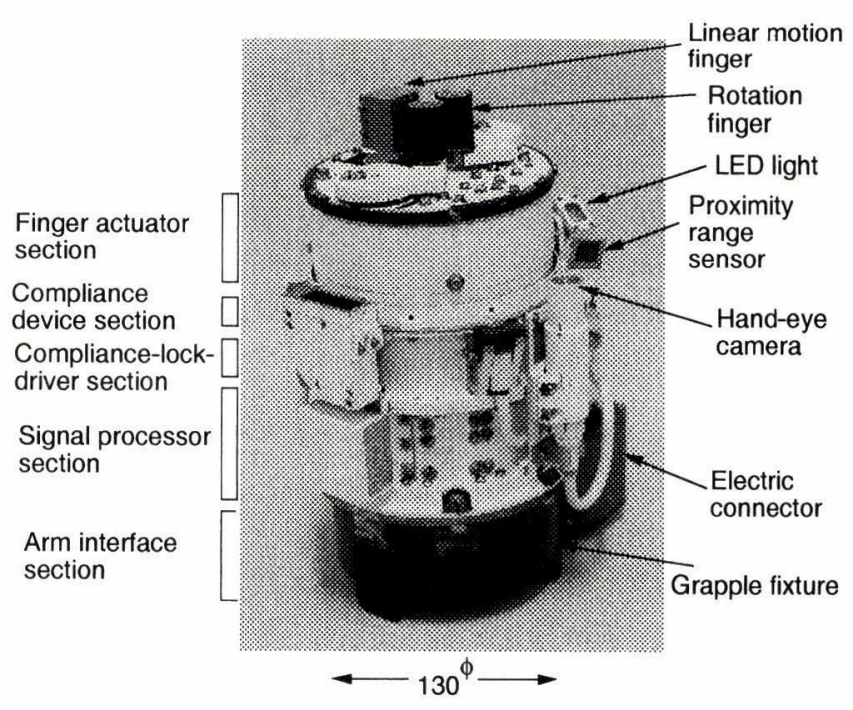

Fig.7 Flight model of the hand

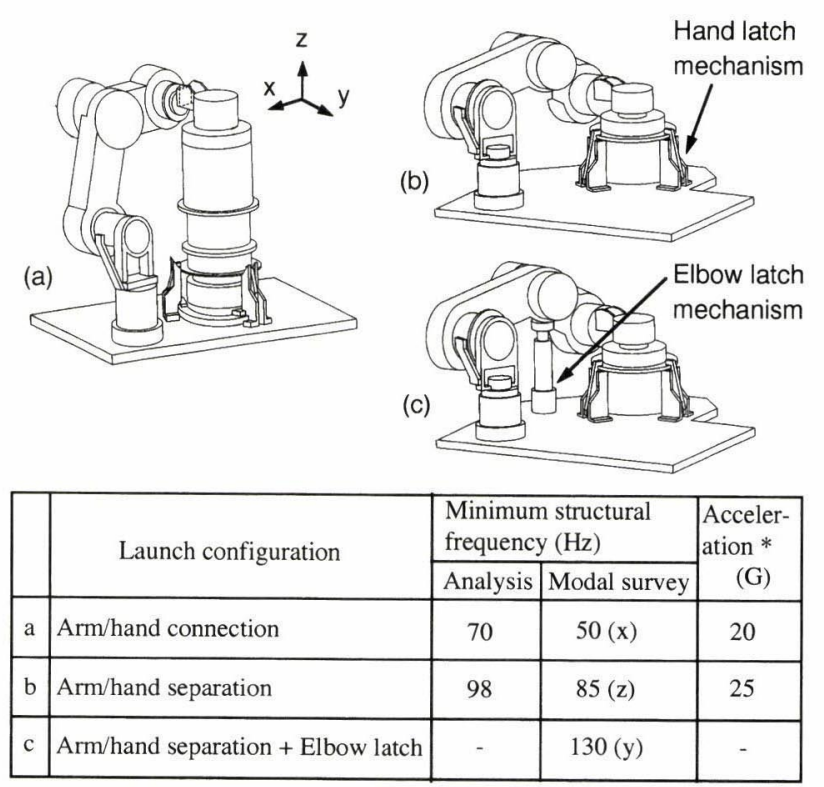

* Acceleration amplitude at minimum structural frequency in $1 \mathrm{G}$ modal survey

Fig.8 Launch configurations of robot arm and structural frequency

も固定する方式である.解析では関節はべアリングの曲げ剛性と 縦剛性拈よびハーモニックドライブのねじり剛性をもつ梁にモデ ル化し，固定部は完全固定とした，その結果，目標を満たす(b) および(c)を候補とした。解析ではクランプなどの接触固定要素 のモデル化が困難なので, 次に実機相当の関節と固定機構を用い た機械構造モデルを試作し共振点探索と $1[\mathrm{G}]$ に対する増幅率を 調べた. 数值解析より固有振動数が 2 割程度低くなっていること がわかる. 方式(b)では固有振動数の要求は満たすが増幅率が 25 となり, Z 軸 $25[\mathrm{G}]$ の正弦波振動条件では数百 $[\mathrm{G}]$ に相当する加 速度が励起され破損することが明らかとなった。したがって, 正 弦波加振範囲（15～ $100[\mathrm{~Hz}])$ に共振モードを持たない(c)方式 
を採用した。

\subsection{2 軌道上再構成}

次に打ち上げ形態から作業形態に再構成する方法を述べる. アームの固定の解除は,「ツール内クランプ爪解除 (Fig. 5 参照) $\rightarrow$ 时固定機構解除 $\rightarrow$ 手首固定機構解除 $\rightarrow$ 手首引き上げ」のシーケ ンスで行う. 振動試験の際, 手首フランジの予圧固定面で微小繰 り返し摩擦のため凝着が起き手首が解放されない場合が生じた。 そのため, 手首の引き上げは以下の手順で行う.

i) 肩ピッチ, 肘ピッチ関節以外をリンプモード(サーボ制御を オフとする)とし, 力制御のもとでステップ状に微小引き上げを 行う. 力が間値を超えた場合は微小量戻した後, 微小引き上げを 続ける.

ii）引き上げ不能ならばモー夕励磁による全軸微小動作後, i） の微小引き上げを行う.

iii）さらに引き上げ不能ならば, 手首ロールを微小回転/反転 させた後，i）の微小引き上げを行う.

方法i）は振動中に生じたアームリンク機構の残留歪みを解放 する効果がある.ii）は全軸を摂動させることによりアームリン ク機構の残留歪みと軽度の凝着を解放しようとするものである. iii）は一般に凝着力は面外方向には大きいが, 剪断方向には小さ いことから行うものである.このように多関節アームの特徴を利 用した引き剥がし動作により振動試験で生じた凝着から解放でき ることが確かめられている。

次にアームとハンドを結合するわけであるが，結合手順は

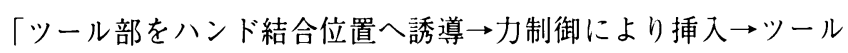

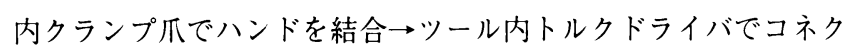
夕をスライド結合」とする.ここで問題となるのは打ち上げの際 に生ずるであろう位置ずれを吸収しかつ過負荷がかからないよう にツールを挿入することである.ここではハンドとアームの結合 インタフェースにガイドを設けるとともに力制御を導入した. ま ず，ガイドに関してはFig.9に示すようにクラウン部内面を並進 ガイドとしアーム側3本爪の側面がこれにならうようにする.ま た,クラウン部の段の側面を回転方向のガイドにする.これらの ガイドは挿入時に時系列的に並進方向( $\mathrm{x}, \mathrm{y})$ の䛊差吸収の後に回転 方向 $(\theta \mathrm{z})$ の誤差吸収がなされるよう位置関係を設計する.並進誤 差吸収では接触点での荷重ベクトル $(F x, F y)$ を力センサ值から算 出し, 力制御により 3 本爪側面をクラウン部内面にならわせて挿 入する. 回転誤差を吸収できる深さまで挿入したら, 次に, 手首 ロール軸をサーボオフとしリンプモードにする.これによりガイ ドにならって回転誤差が修正される.Fig.10にこの方法による八 ンド結合時のデータの一例を示した.ここで初期誤差は並進方向 に $5[\mathrm{~mm}]$, 回転方向に 0.5 度与えているが, 接触後約 50 秒で並 進誤差が修正され, その後約 60 秒で回転誤差が修正されている. 先端力 $10[\mathrm{~N}]$ 程度でハンド結合が行われているのがわかる.この 方法により並進 $\pm 7.5[\mathrm{~mm}]$, 回転士2度の䛊差に対しハンドを結 合できることが確かめられた。

\section{4. 多重センサによる精密作業}

\section{1 基本戦略}

ここでは精密作業を行うための搭載系の計測・制御の基本戦略 を述べる.一般に大きな宇宙施設で作業を行う場合, 精密アーム

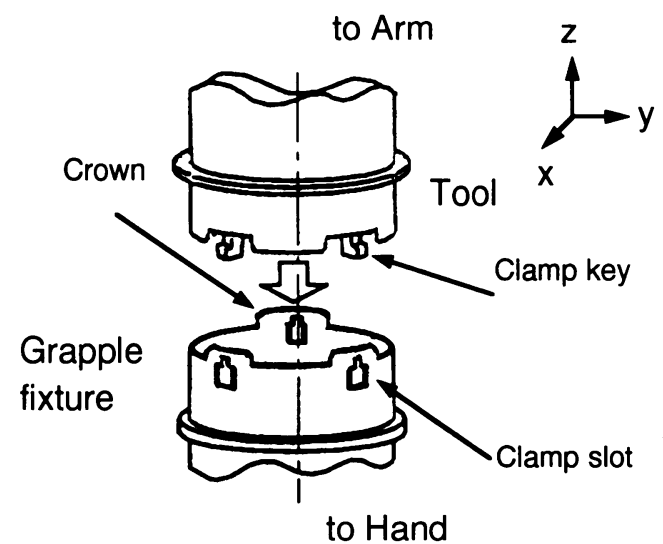

Fig.9 Mechanical interface of arm/hand connection

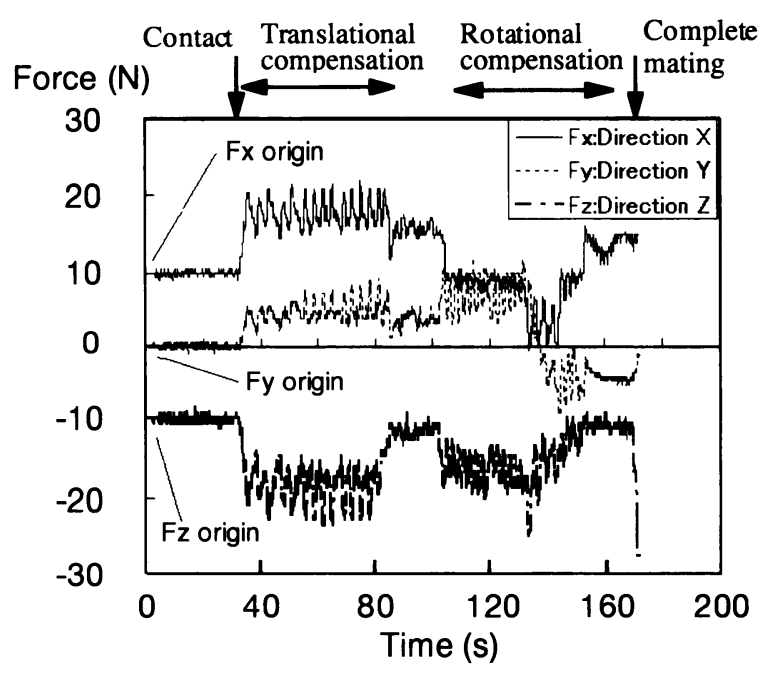

Fig.10 Position error and force during hand connection

は大型アームやトランスポー夕などで粗位置決め後使用される. ここでは土50[mm]の位置決め誤差を前提としてサブミリの精密 作業を行うことを考える．そのためFig.11に示すように，非接 触, 接触の多重センサによりアーム/ハンドを用い能動的にマク ロからマイクロの階層的な計測を行う.ここで近接距離センサは 手首円周上に3等配して取り付けており, ハンドアイカメラと近 接距離センサの光軸は手首ロール軸と平行になるように取り付け ている.まず，ハンドアイカメラにより対象物を探索後，その近 傍で作業面に対して3個の距離センサ值が等しくなるよう手首姿 勢を制御する.これによりハンドアイカメラ軸は作業面に対し垂 直化され, 正面図に相当する画像が得られる。この正面画像を処 理することにより対象物の位置・姿勢を容易に知ることができ る、また，垂直化により局所垂線 ( $\mathrm{z}$ 軸) が得られているので, 対象物近傍の作業面上に単位座標べクトルを規定する印を付けて おくとその画像から $\mathrm{x}-\mathrm{y}-\mathrm{z}$ の局所座標系を生成できる.この局所 座標系での部品の位置を既知とすれば座標系の生成精度とアーム の相対精度で決まる位置決め精度で作業可能となる.

次に近接距離センサを走査し対象物とその近傍の作業環境の断 
Non-contact sensors

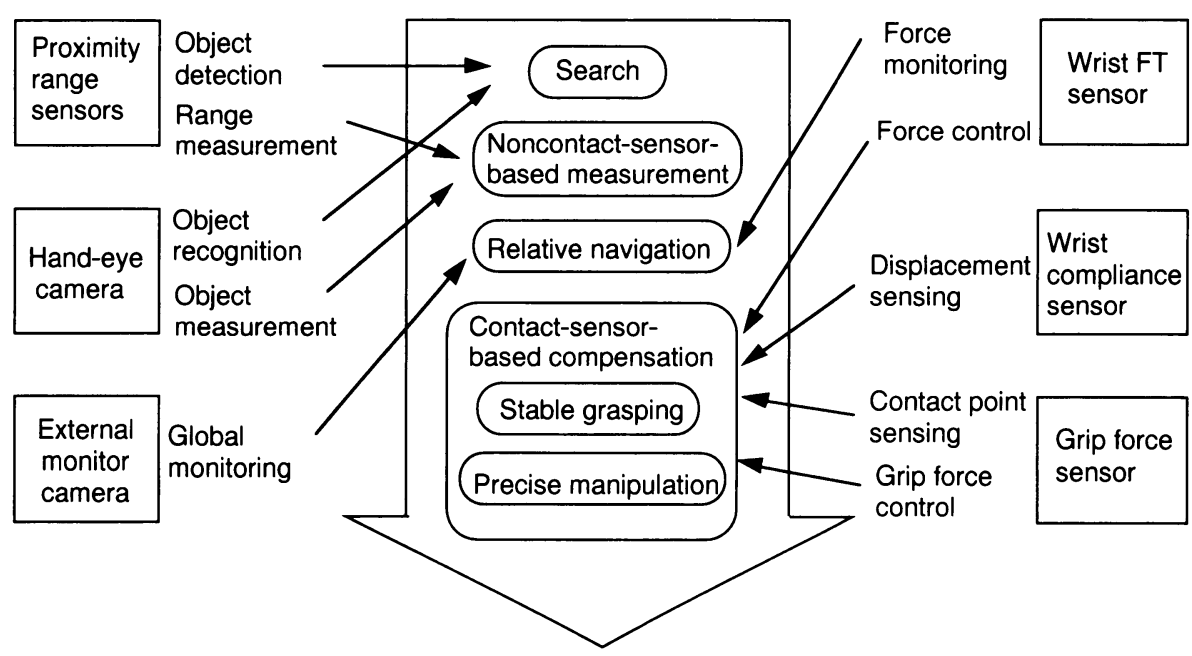

Fig.11 Measurement and control strategy using multisensors

面図に相当する深さ方向のプロファイルを得る。これでハンド の近接ナビゲーションに対する戦略が決定できる。ハンドの移 動は力センサのモ二夕のもとで行い, 万一の衝突による損傷を 防ぐ.

次に，非接触センサの䛊差を吸収するため接触センサベース トの微小補正を行う。対象物を把持する際は把持力七ンサでモ ニタしながら片方の回転指を閉じていく，接触が検出された時 点で止め, もう一方の回転指を接触するまで閉じる.両方の回転 指の角度差が許容值外の場合は把持安定性を得るため，偏差に 応じて手首の位置・姿勢を微調整し再把持するプロセスを繰り 返す。収束後，直動指を閉じ，把持力を制御しながら対象物を しっかりと把持する。この方法によると初期位置誤差があって も対象物にストレスを与えず把持可能となる。コンプライアン ス機構は上記の非接触センサに基づくアームの位置決め最大誤 差（土1.5[mm]）を板バネにより吸収する.中心からの偏差に よる板バネの作用力が好ましくない場合や，偏差を残したまま の挿抜が好ましくない場合には，コンプライアンスセンサによ り検出した変位量をアームの位置制御にフィードバックして微 小補正を繰り返して低減する。これによりアームの相対位置決 め誤差以下に挿入軸の中心を合わせることができる。このアル ゴリズムはコンプライアンス機構で吸収できない大きな䛊差に 遭遇した場合にも, コンプライアンス機構の適用範囲 $( \pm 1.5[\mathrm{~mm}])$ まで追い込むために使用する。

さらに大きな誤差の場合は，カセンサによる疑似コンプライ アンス制御を行う。挿入軸のアライメントは近接距離センサに より高精度に設定できるので $\mathrm{x}, \mathrm{y}, \boldsymbol{\theta}_{\mathrm{z}}$ の 3 軸について力制御を 行い, $\mathrm{z}$ 方向（挿入軸）は一定のストロークで移動させる。すな わち, 挿入しながら反力を検出し, 闎值を超えた場合に以下の補 正を行う.

$$
\begin{aligned}
& \Delta x=M_{y} / k_{1} \\
& \Delta y=M_{x} / k_{2} \\
& \Delta \theta_{z}=-k_{3} M_{z}
\end{aligned}
$$

ここで $k_{1}, k_{2}, k_{3}$ は補正ゲイン $, M_{r}, M_{1}, M_{2}$ はトルクである. $\mathrm{x}, \mathrm{y}$ 方向の補正にトルクデータを用いているのはセンサから接 触点までの距離が約 $15[\mathrm{~cm}]$ と長いため力データより分解能が向 上するためである。この簡易補正法により $5[\mathrm{~mm}]$ の位置誤差 が吸収できることが確かめられた。

\section{2 適用例と評価}

上記の基本戦略の具体的適用をボルトファスナの着脱を例に述 ベる.この種の作業はかじりが起こらないようハンドとボルトの 回転軸の位置と方向を精密に調整する必要があり,特に固体潤滑 膜を用いる宇宙用のボルトファスナではクリティカルな作業要素 の一つである.Fig.12に模式的に作業環境を示す．ボルトを外し ポートにねじ込む。ここでボルトのサイズ,ピッチ，ねじ込み深 さは未知とする。まず, ボルトヘッドをハンドアイカメラで探索 し,ヘッドの六角形の位相に対する指の接近計画を決定する. 次 に前述のように近接距離センサにより $D_{1}=D_{2}=D_{3}$ となるように局 所垂線（Z軸）を設定し，次いで作業パネル面に設けた二つの円 マークを画像計測して原点と Y 軸を設定する. Table 3 に近接七 ンサと視覚センサを複合利用して生成したベース座標系に対する 作業パネルの局所座標要素を機械的計測值と比較して示す.座標 系の生成精度は位置 $\pm 1[\mathrm{~mm}]$, 姿勢 0.3 度以下が達成されてい る.したがってハンドアイカメラの視野が座標マークをとらえる 程度に粗位置決めすれば,アーム相対精度は土0.5 [mm]以下なの で最悪で士 $1.5[\mathrm{~mm}]$ 以下の局所位置決め精度が得られることにな る.

局所位置決め誤差は接触センサベーストの自律制御で微小補正 する.ボルト垂直軸のアライメント合わせは三つの近接センサの 距離情報を用いて行い, 中心合わせは指の接触センシングで行 j. Fig.13 に中心合わせ時の 3 指 A, B, C の位置 $\left(L_{a}, \theta_{b}, \theta_{c}\right), \mathrm{B}$ 指の圧覚値 $\left(F_{n}\right)$, アームの位置補正量 $(\mathrm{dX}, \mathrm{dY})$ を示す。まず，回 転指 $\mathrm{B}$ と C が閉じていき, 約 20 秒でボルトヘッドに接触してい る. 压覚センサで接触を判断して $\mathrm{B}, \mathrm{C}$ 指を止め, 次に直動指 $\mathrm{A}$ を動かしボルトを把持する． B, Cの指の閉じ角 $\left(\theta_{b}, \theta_{c}\right)$ にアンバ ランスが検出されたため把持を解放し，その偏差に応じた量だけ 


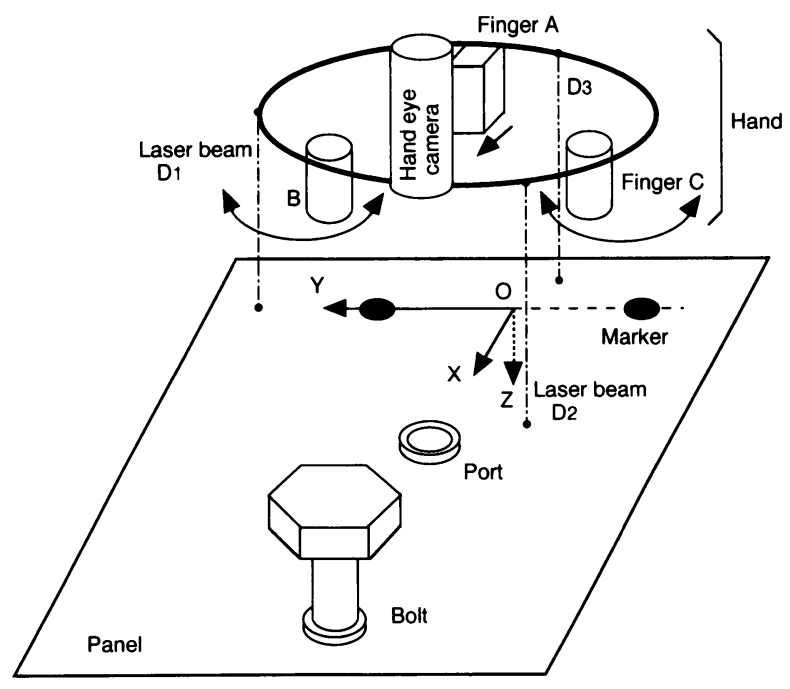

Fig.12 Situation of bolt fastener handling task

Table 3 Coordinate generation by hand sensors

\begin{tabular}{|c|c|c|}
\hline $\begin{array}{c}\text { Coordinate } \\
\text { element of panel }\end{array}$ & $\begin{array}{c}\text { Hand sensor } \\
\text { measurement }\end{array}$ & $\begin{array}{c}\text { Mechanical } \\
\text { measurement }\end{array}$ \\
\hline $\mathrm{X}(\mathrm{mm})$ & 389.713 & 389.252 \\
\hline $\mathrm{Y}(\mathrm{mm})$ & 434.532 & 435.326 \\
\hline$\alpha(\mathrm{deg})$ & 17.098 & 17.099 \\
\hline$\beta(\mathrm{deg})$ & 104.72 & 104.573 \\
\hline
\end{tabular}

アームの水平方向位置を調整する.ここでは $d X=1.66[\mathrm{~mm}], d Y$ $=0.28[\mathrm{~mm}]$ の調整が行われている. 再把持を行うとアンバラン スは解消され中心合わせが完了しているのがわかる.次にボルト の脱作業を手首ロール軸を回転して行う.その時のアームのZ方 向位置 $(Z), \mathrm{Z}$ 方向の力 $(F z)$ とトルク $(M z)$, 指の圧覚值を Fig.14に 示す。ここでは $F z$ と $M z$ をモタしながら 60 度ステップでボル トヘッドを回し，180度回した時点で微小引き抜き動作を行い， 抜けたかどうかを反力 $F z$ で判断する。ここでは反力が認められ たので, 次の 180 度回転のためボルトの持ち換えをするわけであ るが,ボルトが抜ける寸前の状態にあると宇宙空間に放出する恐 れがあるので，60度反対方向にねじ込んでいる，その後，同様 の動作を繰り返してボルトを外す。

ボルトの挿入の際の中心軸合わせは,コンプライアンスセンサ を用いて水平方向変位が閥值内に収まるまで挟み撃ち法でアーム の位置を微小調整して行う.挿入時の過渡衝突力はコンプライア ンス機構により $7[\mathrm{~N}]$ 程度に緩和された。 カセンサを用いる能動 的コンプライアンス制御では制御遅れのためこの数倍のピーク值 となるので,このコンプライアンス機構は剛性の高い対象物の精 密嵌合作業に適している.

このようにして多重センサとハンドメカニズムを利用すること により従来の方法では不可能なサイズ, ピッチ, ねじ込み深さが 不確定な場合のボルトファスナの着脱が可能となった. 同様に前

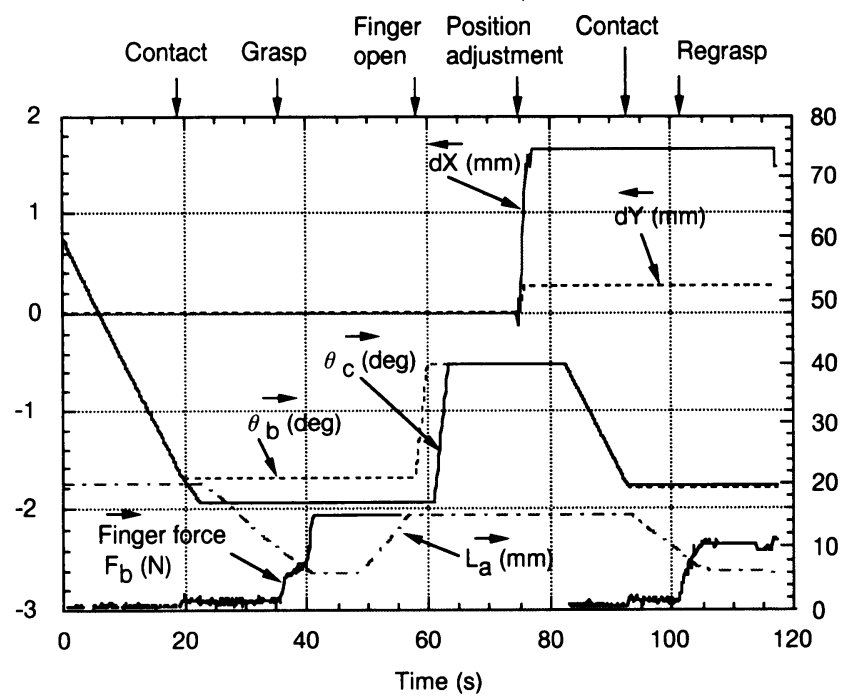

Fig.13 Position adjustment by finger contact sensing

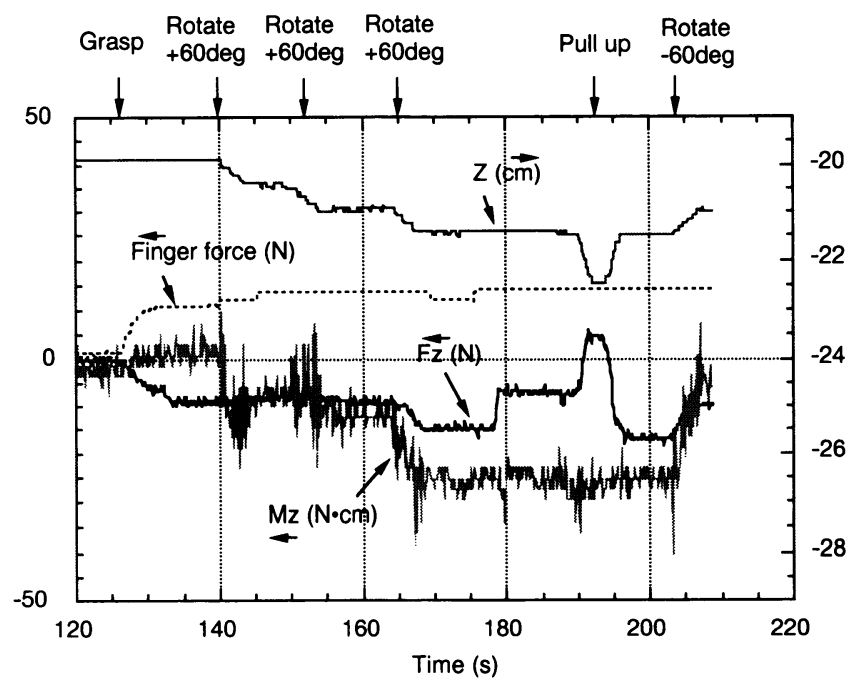

Fig.14 Multisensory control in bolt screwing

節に示した多重センサベーストの作業戦略を応用することによ り, Fig.4のタスクボード上のD-Sub電気コネクタ,ソーラーセ ルシート, 熱ブランケット, ワイヤ, ピンセットなどに対する各 種の精密作業を信頼性高く行えることが地上試験で確認できた [9]. 軌道上での実験結果と評価については今後報告する予定で ある。

\section{5. 開発システム}

開発したフライトモデルの各コンポネントをFig.15に示す.左 から制御計算機，ロボット実験部，タスクパネル，電源装置であ る. 各重量はそれぞれ 7.1, 26.6, 0.7, $8.7[\mathrm{~kg}]$ である. 従来の宇宙 ロボットシステムが $100[\mathrm{~kg}]$ 以上なのに対し, 格段の軽量型シス テムを実現できた.制御計算機は衛星通信系とのテレメトリ/コ マンドの通信処理, 画像取得·処理, 温度制御およびハンド, アー 

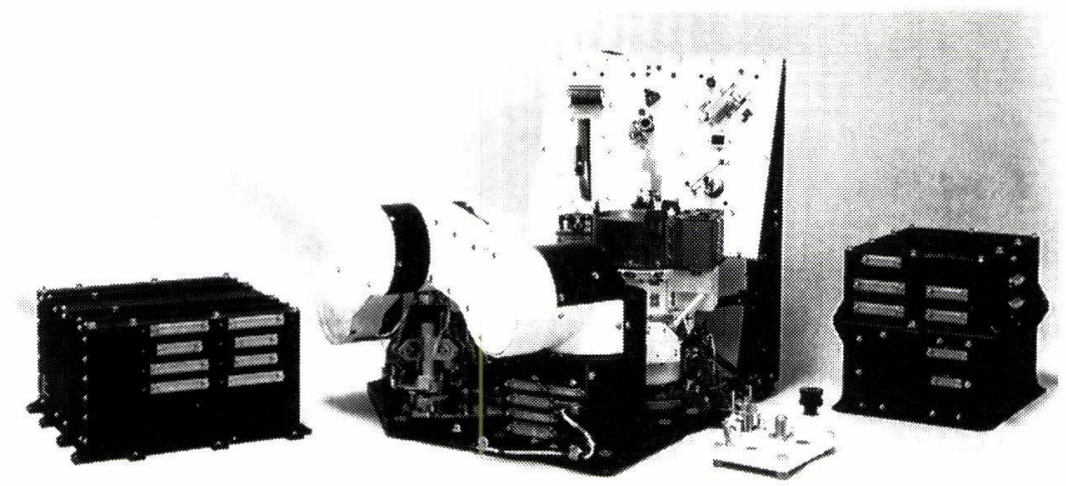

Fig.15 Flight model of the telerobotic system (Control computer, robot experiment unit including hand, arm and taskboard, small task panel, and power unit, from left to right)

ムの制御などを行なう.MPUには80386/387を用い, ROMは 128 $[\mathrm{kB}], \mathrm{RAM} 256[\mathrm{kB}]$ としている。アームのサーボ制御にはDSP （MB8764）を用いている.打ち上げのため,ロボット実験部には アームが折り盢まれて固定され, ハンドも設置機構に分離して固 定されている.タスクパネルはハンド/大型アーム結合実験のた めの部品を収納しておりターゲット衛星に搭載される.電源装置 は衛星の非安定バス電源（32.5～52VDC）から各制御部の定電 圧電源を作るDC/DCコンバータと,アクチュエータドライバ, 熱 制御ヒータのドライバおよびハンドアイカメラのコントローラな どからなる、Fig.16で写真上は単独実験の形態でタスクボードの 部品を扱う地上試験の様子を,下はハンド/大型アーム結合形態 でターゲット衛星上のタスクパネルの部品を扱う地上試験の様子 を示す.

フライトモデルは機能・性能試験, 電磁干渉試験, 振動試験, 熱真空試験などを経た後, 衛星に組み込まれ, システムレベルの 電気系や通信系との適合性試験, 振動試験, 衝撃試験, 熱真空試 験を完了した。Fig.17に衛星の地球指向面に搭載されたロボッ 卜実験装置を示す.

\section{6. 結 び}

技術試験衛星VII型に搭載し部品レベルの精密作業を行うテレ ロボットのシステム設計とフライトモデルの開発について述べ た. 3 指多重センサハンド, 小型アーム, タスクボード, 制御計 算機, 電源装置からなるコンパクトで高機能なロボット実験装置 を開発し, 衛星に搭載可能なシステムを実現した。打上げ環境お よび宇宙環境条件を満たすロボットメカトロニクスの設計,アー ム固定法掞よび軌道上で作業形態に再構成するためのアーム解放 とハンド結合法を示した.さらに, 位置誤差を含む状況で精密作 業を行うため,ハンドメカニズムと多重センサを用いた計測制御 法を述べ, サブミリの精密作業が可能なことを示した。ここで述 べた開発技術の多くは, 小型, 高機能, 精密さが要求される次世 代宇宙ロボットに広く応用しうるものと考えられる。なお,この テレロボットシステムは1997年11月に打ち上げられ，4カ月の 軌道上待機の後, 初期点検が行われ, 正常に機能することが確か められている[10].
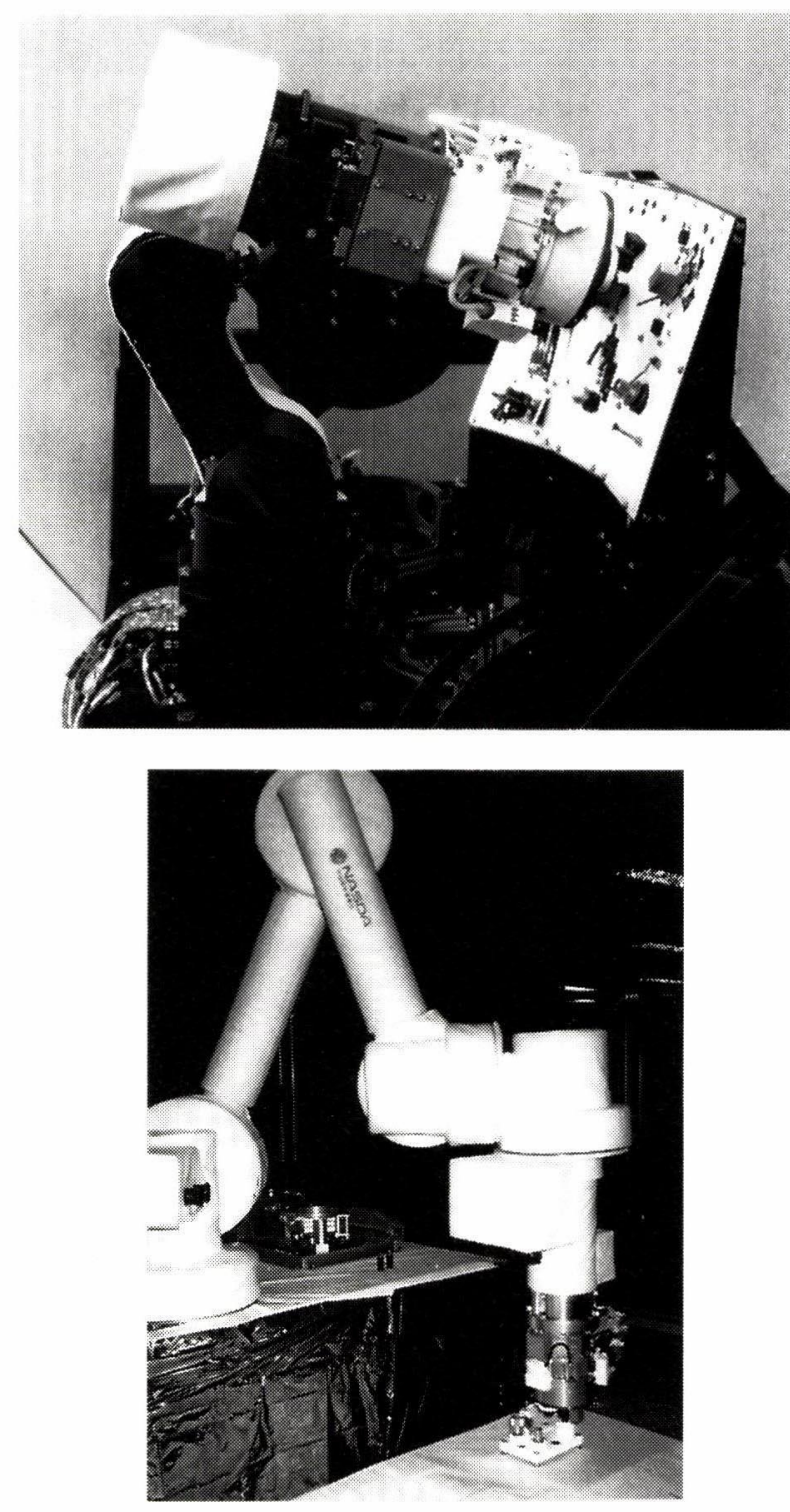

Fig.16 Working configuration in robot experiment (upper: Stand- alone mode, lower: Long-arm connect mode) 


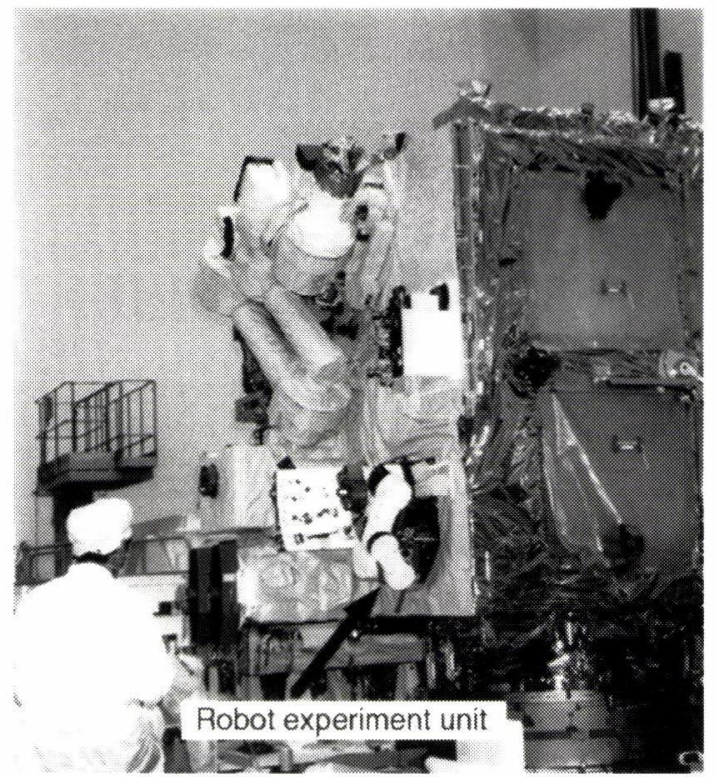

Fig.17 Robot experiment unit of the precise telerobotic system boarded on ETS-VII

謝 辞 本システムの開発にあたり御協力いただいた宇宙開発 事業団およびUSEF 技術委員会の皆様に謝意を表します.

\section{参 考 文 献}

[1] H. Borduas, D. Gossain, A. Kong, E. Quittner and D.S haffer: "Concept Design of the Special Purpose Dexterous Manipulator for the Space Station Mobile Servicing System," Canadian Aeronautics and Space Jour nal, vol.35, no.4, pp.197-204, 1989.

[2] T. Matsueda, F. Kuwano, S. Motohashi and R. Okamura: "Development of Japanese Experiment Module Remote Manipulator System," i-SAIRAS 94, pp.183-186, 1994.

[3] G. Hirzinger, B. Brunner, J. Dietrich and J. Heindel: "Sensor-Based Robotics - ROTEX and Its Telerobotic Features," IEEE Trans. on Robot ics and Automation, vol.9, no.5, pp.649-663, 1993.

[4] K. Machida et.al.: "Preliminary Design of Advanced Robotic Hand for Space Experiment on ETS-VII," ICAR'93, Tokyo, 1993.

[5] 町田, 戸田, 秋田：“ETS-VIIにおける高機能ハンドシステムの宇宙害 験計画”, 第 41 回宇宙科学技術連合講演会, 97-12-7, 1997.

[6] M. Oda: "Engineering Test Satellite VII: Rendezvous, Docking and Space Robot Satellite," i-SAIRAS'97, 1997

[7] 村瀬, 石井, 駒田, 町田, 秋田: “宇宙ロボット用 3 指多重センサハン ドの開発”, 日本ロボット学会誌, vol.16, no.1, pp.124-133, 1998.

[8] K. Machida et. al.: "Precise Space Telerobotic System Using Three-finger Multisensory Hand," IEEE Int Conf. on Robotics and Automation, pp.3238, 1995.

[9] “精密テレロボティクス”, http://www.etl.go.jp/ 5822/spacerobot/precise.html

[10]“高機能ロボットハンドの宇宙実験”, http://www.etl.go.jp/55822/ARH/ index.html

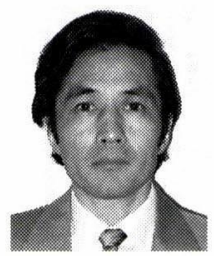

\section{町田和雄 (Kazuo Machida)}

1945 年 8 月 31 日生. 1970 年北海道大学工学研究科 精密工学専攻修士課程修了. 同年, 電子技術総合研 究所入入所. 以後, 宇宙用電気推進システムの研究 に従事. 1982 年より宇宙ロボティクスの研究に従 事. 現在, 宇宙ロボットラボ, 宇宙保全システムラ ボなどのリーダー. 計測自動制御学会, 日本航空宇 宙学会, AIAAなどの会員. 工学博士. (日本ロボット学会正会員)

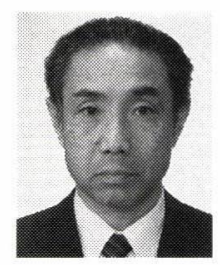

\section{秋田健三 （Kenzo Akita）}

1943 年 2 月 27 日生. 1965 年, 富山大学文理学部理 学科卒業. 同年, 神戸工業 (株) 入入所. 1968 年, 合併により富士通（株）に転籍。1992年，(財) 無 人宇宙実験システム研究開発機構に出向. 技術本 部研究開発第三部長。高機能ロボットハンドの開 発に従事. 工学博士.

\section{三上龍男 (Tatsuo Mikami)}

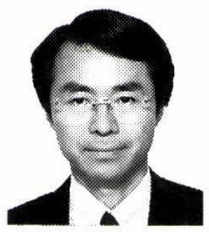

1952 年 8 月 28 日生. 1978 年名古屋大学大学院工学 研究科情報工学専攻修了. 同年, 富士通(株)入社. 以来, 深宇宙軌道決定システムの開発, 宇宙ロボッ 卜の開発等に従事. 宇宙開発推進室第二開発部長. 